Journal of Scientific Perspectives

Volume 3, Issue 2, Year 2019, pp. 159-164

E - ISSN: 2587-3008

URL: http://ratingacademy.com.tr/ojs/index.php/jsp

DOI: https://doi.org/10.26900/jsp.3.016

Review Article

\title{
THE IMPORTANCE OF THE MEDICINAL PLANT NASTURTIUM OFFICINALE L. IN THE ANTICANCER ACTIVITY RESEARCH
}

\author{
Erkan YALÇINKAYA * \& Serdar ÖZGÜÇ**\& Yusuf Orçun TÖRER *** \\ \& Ulvi ZEYBEK ***** \\ * Talaytepe Aile Sağllğı Merkezi, Diyarbakır, TURKEY, E-mail: erkanyalcinkaya@ gmail.com \\ ORCID ID: https://orcid.org/0000-0003-3458-6073 \\ ** Izmir Tabip Odasl, İzmir, TURKEY, E-mail: serdarozguc@gmail.com \\ ORCID ID: https://orcid.org/0000-0001-9904-9098 \\ *** Üzümlü Aile Sağllğı Merkezi, Antalya, TURKEY, E-mail: yusuforcun@gmail.com \\ ORCID ID: https://orcid.org/0000-0003-3434-2132 \\ **** Ege Üniversitesi, Eczacllık Fakültesi, Farmasötik Botanik Anabilim Dall, Bornova, İzmir, \\ TURKEY, E-mail: zeybeku@hotmail.com \\ ORCID ID: https://orcid.org/0000-0003-1053-8771
}

Received: 2 December 2018; Accepted: 27 March 2019

\begin{abstract}
Cancer is known as one of the main cause of death worldwide. It is difficult to discover novel agents that selectively kill tumor cells or inhibit their proliferation without toxicity. Searching for more active and selective compounds with less toxicity is the main target of cancer researches. Nasturtium officinale L. has been used for a long time as a food and medicinal plant. Main therapeutic effects of this plant are due to rich essential nutrients as well as health-promoting plant secondary metabolites such as phenolics and glucosinolates. The plant was repoted to have antiviral, antiinflammatory, diuretic, expectorant, antidiabetic, hepatoprotective, antihyperlipidemic and anticancer properties. The aim of this study is to make review about the previous reports on secondary metabolites of Nasturtium officinale L. in terms of or their effects against various cancer cell lines.
\end{abstract}

Keywords: Antiviral, anti-inflammatory, anticancer, Nasturtium officinale

\section{INTRODUCTION}

Cancer, as a complex disease is still one of the most important causes of deaths today in the modern world. Over a century, the extensive research about the etiopathogenesis of cancer and the studies on developing new drugs, led the scientists to search for new candiates of new anticancer compounds. Unfortunately, because of severe side effects and targeting of single pathways instead of addressing the many factors that enable cancer to develop, the classical chemotherapetics could not reach to aimed success rates. Therefore, recent studies are focused 
on plant secondary metabolites and their semi-synthetic analogues which have multi-targeted effects on cellular signal pathways [1].

\section{MATERIAL AND METHODS}

In the present review, information about medicinal properties and biochemical properties of Nasturtium officinale L., was gathered by searching scientific databases such as Elsevier, Google Scholar, PubMed, Springer, related book chapters and original research articles.

\section{AIM OF THE PRESENT REVIEW}

In the present review, pharmacological properties of Nasturtium officinale L. were discussed and evaluated for future cancer treatments.

\section{MEDICINAL PROPERTIES}

\subsection{Ethnomedicinal Properties}

Nasturtium officinale L., a perennial plant from Brassicaceae family, is traditionally used as raw and cooked form for culinary and for medicinal purposes such as respiratory system diseases, diabetes, oxidative stress, asthma, and immune deficiency [2-12].

\subsection{Therapeutical Properties}

The major active compounds of Nasturtium officinale are found to be phenolic compounds and glucosinolates. Main phenolic compounds were reported to be chlorogenic acid and isorhamnetin. Gluconasturtiin, a precursor of 2-phenylethyl isothiocyanate is reported as a glucosinolate compound with anticarcinogenic and antimicrobial activity. In addition to these secondary metabolites, having high amounts of minerals and with high antioxidant activity, it is worth for searching Nasturtium officinale for cancer protective effects [13-15].

$N$. officinale L. with high content of polyphenolic substances and glucosinolates, may help for anti-inflammatory response and increase antioxidant capacity in cancer patients or patients at high risk group [10,16-22]. Main flavonoids of $N$. officinale L. are found to be quercetin, kaempferol, isorhamnetin, chlorogenic acid, quercetin-3-O-rutinoside, cafeoiltartaric acid and caftaric acid [10,23-24].

Phenylethyl isothiocyanate was found to have an activity to inhibit the migration and invasion of human colorectal carcinoma cells and stop the proliferation of cancer cells. In the cell lines of human breast cancer, phenylethyl isothiocyanate was shown to decrease matrixmetalloprotease-9 and ALDH1 marker and also inhibit tumor invasion [25-27].

$N$. officinale has an angiogenesis inhibitory activity by decreasing the translation regulator 4E protein 1 (4E-BP1) phosphorylation, by decreasing the effect of hypoxia induction factor (HIF) one of the angiogenesis regulators, and by nuclear factor kB (NF-kB), activator protein (AP1) and tubulin. [28]. It was proven to be cancer protective by decreasing DNA damage and regulation of micro RNA's [23, 29-30].

7-methylsulfinylheptyl, 8-methylsulfinyloctyl and sitosterol 3-O-glucopyranoside isolated from $N$. officinale, specifically inhibit p-450 enzymes and activates phase 2 enzymatic reactions [31]. After consumption of Nasturtium officinale, the tobacco smoke specific lung cancer markers 4-(methylnitrosamino)-1-(3-pyridyl)-1-butanol (NNAL) and [4methylnitrosamino)-1-(3-pyridyl) but-1-yl]-beta-omega-D-glucosiduronic acid (NNAL- Gluc) was found to be increased in urine samples at 24 hours and therefore this effect was attributed for anticancer potential of the plant on tobacco-related and other types of lung cancer $[32,33]$. 
Some synergistic activities were also shown between Juglans regia, broccoli and Nasturtium officinale L. extracts [34].

\section{CONCLUSION}

Nasturtium officinale L. can easily be considered as safe because of its traditional culinary use and wide therapeutic range for cancer cell-specific effects that inhibit the cancer cell proliferation.

As a traditional culinary plant with vitamins, minerals and phytonutrients such as isothiosionates and gluconasturtiin, Nasturtium officinale L. may be considered as potential source for anticancer compounds of natural origin. Further in vitro and in vivo studies and clinical researches are needed to be conducted on Nasturtium officinale L. 


\section{REFERENCES}

[1] GIORDANO, S., PETRELli, A., 2008, From Single- to Multi-Target Drugs in Cancer Therapy: When Aspecificity Becomes an Advantage, Current Medicinal Chemistry, 15, 422.

[2] BARKER, D.J., 2009, Pacific Northwest Aquatic Invasive Species Profile: Nasturtium officinale

(Watercress). https://depts.washington.edu/oldenlab/wordpress/wpcontent/uploads/2013/03/Nasturti um-officinale_Barker.pdf

[3] DOLATKHAHI, M., DOLATKHAHI, A., \& NEJAD, J.B., 2014, Ethnobotanical study of medicinal plants used in Arjan- Parishan protected area in Fars Province of Iran. Avicenna journal of phytomedicine, 4(6), 402-12.

[4] ANDRADE, J. M., LUCERO MOSQUERA, H., \& ARMIJOS, C., 2017. Ethnobotany of Indigenous Saraguros: Medicinal Plants Used by Community Healers "Hampiyachakkuna" in the San Lucas Parish, Southern Ecuador. BioMed research international, 9343724.

[5] ABBASI, A.M., KHAN, M.A., SHAH, M.H., SHAH, M.M., PERVEZ, A., AHMAD, M., 2013, Ethnobotanical appraisal and cultural values of medicinally important wild edible vegetables of Lesser Himalayas-Pakistan, J. Ethnobiol. Ethnomed., 9(1), 66.

[6] S. AL-QURA N.,2006. Ethnobotany of Folk Medicinal Potentiality of Aquatic Plants in Jordan. Research Journal of Botany, 1, 75-84.

[7] FLAVIA, L. P., JOSE, M. F., JOAO, P. V. L., 2012. Ethnopharmacological survey: a selection strategy to identify medicinal plants for a local phytotherapy program. Brazilian Journal of Pharmaceutical Sciences, 48, (2).299-313.

[8] FAWZI MAHOMOODALLY, M., PRIYAMKA SREEKEESOON D., 2017, A Quantitative Ethnopharmacological Documentation of Natural Pharmacological Agents Used by Pediatric Patients in Mauritius, BioMed Research International, 1-14.

[9] AIRES, A., CARVAlHO, R., ROSA, E.A.S., SAAVEDRA M. J., 2013, Phytochemical characterization and antioxidant properties of baby-leaf watercress produced under organic production system, CyTA, Journal of Food, 11:4, 343-351.

[10] ZEB, A., 2015, Phenolic profile and antioxidant potential of wild watercress (Nasturtium officinale L.). SpringerPlus, 4, 714.

[11] HARO, G., IKSEN, I., RUMANTİ, R.M., MARBUN, N., SARI, R.P., GULTON, R.P.J., 2018, Evoluation of Antioxidant activity and Minerals Value From Watercress (Nasturtium officinale R.Br.), 11 (1), 232-237.

[12] PAHWA, R., JIALAL, I., 2018, Chronic Inflammation. StatPearls Publishing LLC, Treasure Island (FL).

[13] BALISTRERI, C.R., CARUSO, C., CANDORE, G., 2010, The role of adipose tissue and adipokines in obesity-related inflammatory diseases. Mediat Inflamm, 802078.

[14] LIBRA, M., NICOLETTI, F., 2017, Diet, inflammation and cancer: a journey from prevention to treatment. In: Accardi G, Caruso C, editors. Updates in pathobiology: causality and chance in ageing, age-related diseases and longevity. Palermo, University Press, 145-162.

[15] ACCARDI, G., CARUSO, C., 2018, Immune-inflammatory responses in the elderly: an update. Immun Ageing, 15, 1-11. 
[16] SANTOS J, OLIVEIRA MBPP, IBÁÑEZ E, HERRERO M. 2014, Phenolic profile evolution of different ready-to-eat baby-leaf vegetables during storage. $J$ Chromatogr A.1327:118-31.

[17] AIRES, A., CARVALHO, R., ROSA, EAS, SAAVEDRA, M.J. 2013, Phytochemical characterization and antioxidant properties of baby-leaf watercress produced under organic production system. CyTA- J Food., 11, 343-51.

[18] MARTÍNEZ-SÁNCHEZ, A., GIL-IZQUIERDO, A., GIL, M.I., FERRERES F., 2008, A comparative study of flavonoid compounds, vitamin $\mathrm{C}$, and antioxidant properties of baby leaf Brassicaceae species. J Agric Food Chem., 56, 2330-2340.

[19] DI NOIA, J., 2014, Defining powerhouse fruits and vegetables: a nutrient density approach. Preventing chronic disease, 11, 1-5.

[20] HEBATOLLAH, S., MOSTAFAZADEH, M., SADEGHI, H., MNADERİAN, MEHRZAD JAFARİ BARMAK, MOHAMMAD SHARIF TALEBİANPOOR \& FOUAD MEHRABAN (2014) In vivo anti-inflammatory properties of aerial parts of Nasturtium officinale, Pharmaceutical Biology, 52(2), 169-174.

[21] SHAHANI, S., BEHZADFAR, F., JAHANI, D., GHASEMI, M., SHAKI, F., 2017, Antioxidant and anti-inflammatory effects of Nasturtium officinale involved in attenuation of gentamicin-induced nephrotoxicity, Toxicology Mechanisms and Methods, 27(2), 107-114.

[22] GILL, C.I., HALDAR, S., BOYD, L.A., BENNETT, R., WHITEFORD, J., BUTLER, M., PEARSON, J.R., BRADBURY, I., ROWLAND, I.R., 2007. Watercress supplementation in diet reduces lymphocyte DNA damage and alters blood antioxidant status in healthy adults. Am J Clin Nutr. 85, 504-510.

[23] LAI K.C., HSU, S.C., KUO, C.L., IP, S.W., YANG, J.S., HSU, Y.M., HUANG H.Y., WU S.H., CHUNG, J.G., 2010, Phenethyl Isothiocyanate Inhibited Tumor Migration and Invasion via Suppressing Multiple Signal Transduction Pathways in Human Colon Cancer HT29 Cells, Journal of Agricultural and Food Chemistry, 58 (20), 11148-11155.

[24] PEREIRA LUCÍLIA, P., SILVA P., DUARTE, M., RODRIGUES, L., DUARTE C. M. M, ALBUQUERQUE, C., TERESA SERRA, A., 2017, Targeting Colorectal Cancer Proliferation, Stemness and Metastatic Potential Using Brassicaceae Extracts Enriched in Isothiocyanates: A 3D Cell Model-Based Study, Nutrients, 9(4), 368.

[25] ROSE, P., HUANG, Q., ONG, C.N., WHITEMAN, M., 2005, Broccoli and watercress suppress matrix metalloproteinase-9 activity and invasiveness of human MDA-MB-231 breast cancer cells. Toxicol Appl Pharmacol. 209 (2), 105-113.

[26] SYED ALWI, S. S., CAVELL, B. E., TELANG, U., MORRIS, M. E., PARRY, B. M., PACKHAM, G., 2010, In vivo modulation of 4E binding protein 1 (4E-BP1) phosphorylation by watercress: a pilot study. The British journal of nutrition, 104 (9), 1288-96.

[27] CAVELl, B.E., SYED ALWI S.S., DONLEVY, A., PACKHAM, G., 2011, Antiangiogenic effects of dietary isothiocyanates: mechanisms of action and implications for human health, Biochem Pharmacol. 81 (3), 327-36.

[28] PAN, J H., ABERNATHY, B., KIM, Y. J., LEE J. H., KIM, J. H., SHIN, E. C., KIM J. K., 2018, Cruciferous vegetables and colorectal cancer prevention through microRNA regulation: A review, Critical Reviews in Food Science and Nutrition, 58 (12), 20262038 . 
[29] FOGARTY, M.C., HUGHES, C.M., BURKE, G., BROWN, J.C., DAVISON, G.W., 2013, Acute and chronic watercress supplementation attenuates exercise-induced peripheral mononuclear cell DNA damage and lipid peroxidation, Br J Nutr. 109 (2), 293-301.

[30] ROSE, P., FAULKNER, K., WILliAMSON, G., MITHEN, R., 2000, 7Methylsulfinylheptyl and 8-methylsulfinyloctyl isothiocyanates from watercress are potent inducers of phase II enzymes, Carcinogenesis, 21 (11), 1983-1988.

[31] YAZDANPARAST, R., BAHRAMIKIA, S., ARDESTANI, A., 2008, Nasturtium officinale reduces oxidative stress and enhances antioxidant capacity in hypercholesterolaemic rats, Chem Biol Interact., 172 (3):176-84

[32] HECHT, S.S., CHUNG, F.L, RICHIE, JR J.P., AKERKAR, S. A., BORUKHOVA, A, SKOWRONSKI, L., CARMELLA, S. G., 1995, Effects of watercress consumption on metabolism of a tobacco-specific lung carcinogen in smokers, Cancer Epidemiol Biomarkers Prev., 4 (8), 877-884.

[33] HOSSEINI S. A., MOHAMMADI, J., DELAVIZ H., SHARIATI, M., Effect of Juglansregia and Nasturtum officinalis on biochemical parameters following toxicity of kidney by CCl4 in Wistar rats, Electron J Gen Med., 15(3), 1-7.

[34] GINTING, H., DALIMUNTHE, A., REWENY, J., 2017, Acute Toxicity Effect of The Ethanolic Extract of Watercress Herb (Nasturtium officinale R. Br.) in Mice, Indonesian J. of Cancer Chemoprevention, 7, 9-16. 